\title{
Analysis of Fire Hazards in a Selected Plant
}

\author{
A. Kawałek, K. Choromańska \\ Czestochowa University of Technology, Poland \\ K. Ozmegov \\ National University of Science and Technology \\ "MISIS", Moscov, Russian Federation
}

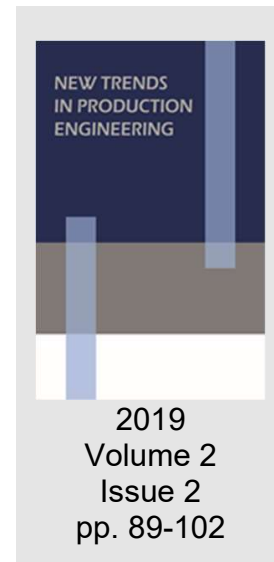

Date of submission to the Editor: 09/2019

Date of acceptance by the Editor: 11/2019

\section{INTRODUCTION}

An indispensable element of an enterprise's functioning is striving for the minimization or elimination of losses. To this end, proper safety management is necessary, whose essential element is risk management (Jarysz-Kamińska, 2013, Kokot-Stępień, 2015, Michalak, 2004). The basic purpose of the risk management process is to identify the greatest possible number of risks occurring in the enterprise's environment and to determine the method of their elimination (Jajuga, 2005, Jajuga, 2009, Kaczmarek, 2008).

Fire safety is a state that eliminates threats to human life or health, which is achieved by the functioning of a system of rules of law and fire protection technical standards, as well as pursued fire protection activities (Janicka-Panek, 2015, Grabowska-Lepczak, 2017, Grocki, 2003).

Refuelling stations are among exceptionally dangerous workplaces, and therefore they require special precautions to be taken both by the owners and the employees. Fluid fuels are substances classified into the group of particularly dangerous materials. They create high toxicological risk, fire risk, as well as explosion risk (Dyb et al., 2010, Asystentbhp.pl, 2019).

Therefore, it is of paramount importance to conduct risk analysis aimed at their identification and, at the subsequent stage, the determination of the effects of those risks and the probability of their occurrence. As a result of the analysis, the risk of the occurrence of each of these risks is estimated. This makes it possible to verify whether the safety system existing in the enterprise fulfils its purpose.

Fire risks and the assurance of enterprise safety are, in this respect, often underestimated, and any activities undertaken by employers are caused exclusively by the obligation imposed by safety regulations rather than by the genuine understanding of the risks of potential fires.

It is therefore crucial to have effective procedures and processes developed, which will ensure the employees healthy and safe working conditions. 
The purpose of the study was to identify and analyze fire risks in a selected plant - a fuel base. Based on the analysis carried out, the risk of those risks occurring For the estimation of the risk of fire hazard occurrence, the PHA met hod was used.

\section{RESEARCH METHODOLOGY}

There are many methods that may serve to identify hazards (Krause, 2016, Zawieska, 2009). The most common methods for identifying hazards in the chemical and petrochemical industries are: the HAZOP (Hazard and Operability Study) (Pruszkowski, 2015, PN-EN 61882:2016-07, 2016, Kunicki et al., 2001), method and the PHA (Preliminary Hazard Analysis) method (Krause, 2011, Czerwińska \& Pacana, 2018, Romanowska-Słomka \& Słomka, 2008). PHA is an induction method that enables the qualitative estimation of risk. It is designed for the estimation of risk associated with hazards, hazardous situations and hazardous incidents that occur on machinery and equipment and in their systems and subsystems. The purpose of the PHA method is to determine the magnitude of the risk of individual hazardous events using two parameters. The first of them is parameter $\mathrm{P}$ - probability, selected based on the characteristics provided in Table 1 (Janicka-Panek, 2015). The second parameter is the level of effects - S, defined based the characteristics given in Table 2 (JanickaPanek, 2015, Rączkowski, 1999).

Table 1 The value of probability $\mathbf{P}$ and the frequency of event occurrence
\begin{tabular}{|c|l|}
\hline LEVEL OF PROBABILITY (P) & \multicolumn{1}{c|}{ DESCRIPTION } \\
\hline A & Highly improbable $(1 / 1.000 .000)$ \\
\hline B & Little probable $(1 / 20.000)$ \\
\hline C & Incidental event $(1 / 4.000)$ \\
\hline D & Fairly frequent event $(1 / 400)$ \\
\hline E & Regular event (1/40) \\
\hline F & High probability event $(1 / 4)$ \\
\hline
\end{tabular}

Source: Compiled based on (Janicka-Panek, 2015)

Table 2 Level of effects S

\begin{tabular}{|c|c|c|c|c|}
\hline \multicolumn{5}{|c|}{ DESCRIPTION } \\
\hline $\begin{array}{l}\text { DAMAGE } \\
\text { LEVEL, S }\end{array}$ & $\begin{array}{c}\text { PEOPLE } \\
\text { L }\end{array}$ & $\begin{array}{c}\text { PROPERTY } \\
M\end{array}$ & $\begin{array}{c}\text { ENVIRONMENT } \\
\mathrm{S}\end{array}$ & $\begin{array}{c}\text { REPUTATION } \\
\text { R }\end{array}$ \\
\hline 1 & No injuries & No damage & No influence & No effect \\
\hline 2 & Slight injuries & Minor damage & Small influence & Minor effect \\
\hline 3 & $\begin{array}{l}\text { Severe } \\
\text { injuries }\end{array}$ & $\begin{array}{l}\text { Localized } \\
\text { damage }\end{array}$ & $\begin{array}{l}\text { Localized } \\
\text { influence }\end{array}$ & $\begin{array}{l}\text { Localized } \\
\text { effect }\end{array}$ \\
\hline 4 & Isolated fatalities & $\begin{array}{l}\text { Considerable } \\
\text { damage }\end{array}$ & $\begin{array}{l}\text { Long-lasting } \\
\text { influence }\end{array}$ & $\begin{array}{l}\text { Regional } \\
\text { effect }\end{array}$ \\
\hline 5 & Mass fatalities & $\begin{array}{l}\text { Very large-scale } \\
\text { damage }\end{array}$ & $\begin{array}{l}\text { Vast environmental } \\
\text { damage }\end{array}$ & $\begin{array}{l}\text { Nationwide } \\
\text { effect }\end{array}$ \\
\hline 6 & $\begin{array}{l}\text { Fatalities outside } \\
\text { the plant }\end{array}$ & Total destruction & $\begin{array}{l}\text { Vast beyond-local } \\
\text { environmental } \\
\text { damage }\end{array}$ & $\begin{array}{l}\text { International } \\
\text { effect }\end{array}$ \\
\hline
\end{tabular}

Source: Compiled based on (Janicka-Panek, 2015)

The magnitude of risk is defined by the following formula:

$$
\mathrm{R}=\mathrm{P} \cdot \mathrm{S}
$$

where:

$\mathrm{P}$ - probability of damage occurrence; 
S - damage level.

Estimating the values of $\mathrm{P}$ (Table 1) and $\mathrm{S}$ (Table 2) takes place at six levels for each identified hazard.

After estimating the above parameters, the risk index is determined based on the risk matrix shown in Table 3 (Janicka-Panek, 2015).

Table 3 The risk matrix according to the PHA method

\begin{tabular}{|c|c|c|c|c|c|c|c|}
\hline \multicolumn{7}{|c|}{ PROBABILITY OF DAMAGE OCCURRENCE (P) } \\
\hline \multirow{3}{*}{$\begin{array}{c}\text { DAMAGE } \\
\text { LEVEL (S) }\end{array}$} & 1 & $\mathbf{A}$ & $\mathbf{B}$ & $\mathbf{C}$ & $\mathbf{D}$ & $\mathbf{E}$ & $\mathbf{F}$ \\
\cline { 2 - 8 } & 2 & 2 & 2 & 3 & 4 & 5 & 6 \\
\cline { 2 - 8 } & 3 & 3 & 6 & 6 & 8 & 10 & 12 \\
\cline { 2 - 8 } & 4 & 4 & 8 & 12 & 12 & 15 & 18 \\
\cline { 2 - 8 } & 5 & 5 & 10 & 15 & 20 & 25 & 30 \\
\hline
\end{tabular}

Source: Compiled based on (Janicka-Panek, 2015)

The level of risk is estimated based on the three-stage scale:

- The range of values 1-3, acceptable risk;

- The range of values 4-9, permissible risk;

- The range of values 10-36, impermissible risk.

\section{DESCRIPTION OF THE RESEARCH OBJECT}

The Fuel Base under analysis has been functioning since 2001 in the area of the liquidated part of a Coal Mine. The Terminal deals with receiving, storing, delivering and upgrading petroleum products, such as unleaded petrol $\mathrm{Pb} 98$, unleaded petrol $\mathrm{Pb} 95$ and diesel oil. Moreover, the Terminal is adapted to the storage of biofuel components. The Fuel Base's handling capacity in unloading railway cisterns is 2.8 millions tons/year, while in unloading road tankers, 1.8 million tons/year. The terminal operates in a continuous 24/7 system, i.e. 24 hours a day, 7 days per week. The Fuel Base is a plant of an increased risk of the occurrence of a serious failure.

The Fuel Base has the following facilities:

- a railway cistern unloading bay,

- an engineering pumping station with unloading and loading bay pumps,

- a $3000 \mathrm{~m}^{3}$ - apacity gasholder - 1 pc.

- a tanker loading bay,

- a vapour recovery installation - vru,

- $2000 \mathrm{~m}^{3}$ ground vertical fuel storage tanks designed for storing petroleum products of classes i and iii - 2 pcs.,

- ground vertical fuel storage tanks, each of a working capacity of $8000 \mathrm{~m}^{3}$, designed for storing petroleum products of classes i and iii -4 pcs.,

- a $6000 \mathrm{~m}^{3}$ ground vertical fuel storage tank designed for storing petroleum products of classes i and iii - 1 pc.,

- ground vertical fuel storage tanks, each of a capacity of $10000 \mathrm{~m}^{3}-9$ pcs.,

- a $3000 \mathrm{~m}^{3}$ vertical ground fuel storage tank designed for storing petroleum products of class iii -1 pc., 
- underground fuel additive and upgrading agent tanks, each of a capacity of $100 m^{3}-4$ pcs.,

- ground horizontal biofuel storage tanks, each of a capacity of $200 \mathrm{~m}^{3}-2$ pcs.,

- a $750 \mathrm{~m}^{3}$ ground vertical fuel storage tank designed for storing higher fatty acid methyl esters - 1 pc.,

- a $750 \mathrm{~m}^{3}$ vertical ground fuel storage tank designed for storing petroleum products of class iii, i.e. diesel oil - 1 pc.,

- a biofuel additive tanker unloading station,

- a multi-function building,

- low trestle bridges,

- a technical yard protected with tight attested HDPE foil,

- other facilities associated with handling, and the energy and water management of the Fuel Base,

- a railway system adapted to the operation of the Fuel Base,

- fencing,

- a potable and fire-fighting water-pipe network,

- industrial waste, storm water and sewage drain systems,

- a telephone and an alarm networks.

The Fuel Base's technical infrastructure performs the following functions:

- the receipt, storage and distribution of fuels, fuel additives and biocomponents for fuels and biofuels,

- the recovery of hydrocarbons from the air discharged to the atmosphere,

- settling and recording the fuel trade and inventories,

- fire protection of the Fuel Base,

- creating the proper working conditions for the staff,

- ground protection against contamination by petroleum products,

- provision with energy utilities,

- waste water cleaning and discharge,

- access control,

- reduction of the potential for the occurrence of a major industrial failure, as well as the mitigation of its potential effects.

The identification and analysis of fire hazards was made for a selected facility of the Fuel Base's main centres: the farm of store tanks. The performed analysis established the method of preventing those hazards.

\section{THE STORAGE TANK FARM}

For the storage of fuels, 17 ground vertical steel double-bottom storage tanks along with cylindrical steel shields and leak sensors are used. They are designed for storing petroleum products in temperature classes I and III - petrols PB 95 and 98 and diesel oil.

The storage tank farm includes tanks divided into the following groups:

Group 1 - designed for storing petroleum products belonging to classes I and III:

- one $2000 \mathrm{~m}^{3}$ capacity tank;

- four tanks, each of a capacity of $2000 \mathrm{~m}^{3}$; 
- one $2000 \mathrm{~m}^{3}$ capacity tank.

Group 2 - designed for storing petroleum products belonging to classes I and III:

- three $10000 \mathrm{~m}^{3}$ capacity tanks.

Group 3 - designed for storing petroleum products belonging to classes I and III:

- two $10000 \mathrm{~m}^{3}$ capacity tanks;

- one $2000 \mathrm{~m}^{3}$ capacity tank.

Group 4 - designed for storing petroleum products belonging to class III:

- four $10000 \mathrm{~m}^{3}$ capacity tanks.

Group 5 - designed for storing biocomponents, such as esters, ethanol:

- one $750 \mathrm{~m}^{3}$ capacity tank;

- two $200 \mathrm{~m}^{3}$ capacity horizontal tanks.

And moreover:

- one $3000 \mathrm{~m}^{3}$ capacity tank - designed for storing petroleum products belonging to class III

- one $750 \mathrm{~m}^{3}$ capacity tank - designed for storing diesel oil.

Table 4 The types and effects of fire hazards and fire prevention measures for the storage tank farm

\begin{tabular}{|c|c|c|c|c|c|c|c|c|}
\hline \multicolumn{9}{|c|}{ STORAGE PARK FARM } \\
\hline \multirow[b]{2}{*}{ No. } & \multirow[b]{2}{*}{$\begin{array}{c}\text { Hazardous } \\
\text { event }\end{array}$} & \multirow[b]{2}{*}{ Effects } & \multirow{2}{*}{$\begin{array}{l}\text { Precautions, } \\
\text { preventive } \\
\text { safety systems } \\
\text { (existing) }\end{array}$} & \multicolumn{4}{|c|}{ Risk } & \multirow[b]{2}{*}{$\begin{array}{c}\text { General } \\
\text { risk }\end{array}$} \\
\hline & & & & $\mathbf{L}$ & M & $\mathbf{S}$ & $\mathbf{R}$ & \\
\hline \multirow[b]{2}{*}{1} & \multirow[b]{2}{*}{$\begin{array}{l}\text { A leak at the } \\
\text { tank outflow } \\
\text { connection } \\
\text { before } \\
\text { the cut-off valve }\end{array}$} & Leak & $\begin{array}{l}\text { - tank curtain wall } \\
\text { - processes } \\
\text { measurement } \\
\text { and control } \\
\text { system, } \\
\text { - industrial } \\
\text { draining system, } \\
\text { - ground } \\
\text { protection, } \\
\text { - underground } \\
\text { water monitoring } \\
\text { - permanent } \\
\text { operation } \\
\text { supervision } \\
\end{array}$ & $\begin{array}{l}\text { C1 } \\
(3)\end{array}$ & $\begin{array}{l}\text { C1 } \\
\text { (3) }\end{array}$ & $\begin{array}{l}\text { C2 } \\
(6)\end{array}$ & $\begin{array}{l}\text { C1 } \\
\text { (3) }\end{array}$ & C2 (6) \\
\hline & & Fire & $\begin{array}{l}\text { - as above, } \\
\text { - sprinkler } \\
\text { system, } \\
\text { - fire-fighting } \\
\text { system, } \\
\text { - fixed foam } \\
\text { extinguisher } \\
\text { system, } \\
\text { - lightning } \\
\text { protection and } \\
\text { static electricity } \\
\text { discharge } \\
\text { system, } \\
\text { - hydrant } \\
\text { installation - } \\
\text { water and foam, } \\
\text { - prohibition of } \\
\text { using tools other } \\
\text { than in Ex } \\
\text { execution, }\end{array}$ & $\begin{array}{l}B 2 \\
(4)\end{array}$ & $\begin{array}{l}\text { B4 } \\
(8)\end{array}$ & $\begin{array}{l}\text { B2 } \\
(4)\end{array}$ & $\begin{array}{l}\text { B3 } \\
\text { (6) }\end{array}$ & B4 (8) \\
\hline
\end{tabular}




\begin{tabular}{|c|c|c|c|c|c|c|c|c|}
\hline & & & $\begin{array}{l}\text { - alarming } \\
\text { system, } \\
\text { - close-circuit } \\
\text { television } \\
\text { system. }\end{array}$ & & & & & \\
\hline & & Explosion & - as above, & $\begin{array}{l}\text { B4 } \\
(8)\end{array}$ & $\begin{array}{l}\text { B4 } \\
\text { (8) }\end{array}$ & $\begin{array}{l}\text { B3 } \\
\text { (6) }\end{array}$ & $\begin{array}{l}\text { B4 } \\
\text { (8) }\end{array}$ & B4 (8) \\
\hline \multirow{3}{*}{2} & \multirow{3}{*}{$\begin{array}{l}\text { Storage tank } \\
\text { bursting }\end{array}$} & Leakage & - as under point 1 & $\begin{array}{l}\text { B1 } \\
\text { (2) }\end{array}$ & $\begin{array}{l}\text { B1 } \\
\text { (2) }\end{array}$ & $\begin{array}{l}\text { B2 } \\
\text { (4) }\end{array}$ & $\begin{array}{l}\text { B2 } \\
\text { (4) }\end{array}$ & B2 (4) \\
\hline & & Fire & - as above, & $\begin{array}{l}\text { B3 } \\
\text { (6) }\end{array}$ & $\begin{array}{l}\text { B4 } \\
\text { (8) }\end{array}$ & $\begin{array}{l}\text { B2 } \\
\text { (4) }\end{array}$ & $\begin{array}{l}\text { B3 } \\
\text { (6) }\end{array}$ & B4 (8) \\
\hline & & Explosion & - as above, & $\begin{array}{l}\text { B4 } \\
(8)\end{array}$ & $\begin{array}{l}\text { B4 } \\
\text { (8) }\end{array}$ & $\begin{array}{l}\text { B3 } \\
\text { (6) }\end{array}$ & $\begin{array}{l}\text { B4 } \\
(8)\end{array}$ & B4 (8) \\
\hline \multirow{3}{*}{3} & \multirow{3}{*}{$\begin{array}{l}\text { Failure of the } \\
\text { automatic pump } \\
\text { control system } \\
\text { - tank } \\
\text { overflowing }\end{array}$} & Leakage & $\begin{array}{l}\text { - as under point } 1 \\
\text { - with no } \\
\text { measuring and } \\
\text { control systems }\end{array}$ & $\begin{array}{l}\text { C1 } \\
\text { (3) }\end{array}$ & $\begin{array}{l}\mathrm{C} 2 \\
(6)\end{array}$ & $\begin{array}{l}\text { C1 } \\
\text { (3) }\end{array}$ & $\begin{array}{l}\text { C1 } \\
\text { (3) }\end{array}$ & C2 (6) \\
\hline & & Fire & - as above, & $\begin{array}{l}\text { C3 } \\
\text { (9) }\end{array}$ & $\begin{array}{l}\text { C3 } \\
\text { (9) } \\
\end{array}$ & $\begin{array}{l}\mathrm{C} 2 \\
\text { (6) }\end{array}$ & $\begin{array}{l}\text { C3 } \\
\text { (9) }\end{array}$ & C3 (9) \\
\hline & & Explosion & - as above, & $\begin{array}{l}\text { B4 } \\
\text { (8) }\end{array}$ & $\begin{array}{l}\text { B4 } \\
\text { (8) }\end{array}$ & $\begin{array}{l}\text { B2 } \\
\text { (4) }\end{array}$ & $\begin{array}{l}\text { B4 } \\
\text { (8) }\end{array}$ & B4 (8) \\
\hline \multirow[b]{2}{*}{4} & \multirow{2}{*}{$\begin{array}{l}\text { Unsealing } \\
\text { vapour recovery } \\
\text { system - } \\
\text { a break } \\
\text { of the pipeline } \\
\text { or fittings }\end{array}$} & $\begin{array}{l}\text { Vapour } \\
\text { emissions }\end{array}$ & $\begin{array}{l}\text { - processes } \\
\text { measurement } \\
\text { and control } \\
\text { system, } \\
\text { - inspection } \\
\text { and } \\
\text { maintenance, } \\
\text { - permanent } \\
\text { operation } \\
\text { supervision }\end{array}$ & $\begin{array}{l}\text { B1 } \\
(2)\end{array}$ & $\begin{array}{l}\text { B2 } \\
\text { (4) }\end{array}$ & $\begin{array}{l}\text { B2 } \\
\text { (4) }\end{array}$ & $\begin{array}{l}\text { B1 } \\
\text { (2) }\end{array}$ & B2 (4) \\
\hline & & Fire/explosion & $\begin{array}{l}\text { - as above, } \\
\text { - lightning } \\
\text { protection and } \\
\text { static electricity } \\
\text { discharge } \\
\text { system, } \\
\text { - prohibition of } \\
\text { using tools other } \\
\text { than in Ex } \\
\text { execution } \\
\text { - antiknock } \\
\text { protective } \\
\text { devices. }\end{array}$ & $\begin{array}{l}\text { B3 } \\
\text { (6) }\end{array}$ & $\begin{array}{l}\text { B3 } \\
\text { (6) }\end{array}$ & $\begin{array}{l}\text { B2 } \\
\text { (4) }\end{array}$ & $\begin{array}{l}\text { B3 } \\
\text { (6) }\end{array}$ & B3 (6) \\
\hline \multirow[b]{2}{*}{5} & \multirow[b]{2}{*}{$\begin{array}{l}\text { Safety valve } \\
\text { damage }\end{array}$} & $\begin{array}{l}\text { Vapour } \\
\text { emission }\end{array}$ & $\begin{array}{l}\text { - as under point } \\
4, \\
\text { - vapour recovery } \\
\text { system }\end{array}$ & $\begin{array}{l}\text { D1 } \\
\text { (4) }\end{array}$ & $\begin{array}{l}\text { D1 } \\
(4)\end{array}$ & $\begin{array}{l}\text { D2 } \\
\text { (8) }\end{array}$ & $\begin{array}{l}\text { D1 } \\
\text { (4) }\end{array}$ & D2 (8) \\
\hline & & Fire/explosion & $\begin{array}{l}\text { - as above, } \\
\text { - lightning } \\
\text { protection and } \\
\text { static electricity } \\
\text { discharge } \\
\text { system, } \\
\text { - prohibition of } \\
\text { using tools other } \\
\text { than in Ex } \\
\text { execution }\end{array}$ & $\begin{array}{l}\mathrm{C} 2 \\
\text { (6) }\end{array}$ & $\begin{array}{l}\text { C3 } \\
\text { (9) }\end{array}$ & $\begin{array}{l}\mathrm{C} 2 \\
\text { (6) }\end{array}$ & $\begin{array}{l}\text { C2 } \\
\text { (6) }\end{array}$ & C3 (9) \\
\hline 6 & $\begin{array}{l}\text { Tank } \\
\text { overheating }\end{array}$ & $\begin{array}{l}\text { Vapour } \\
\text { emission }\end{array}$ & $\begin{array}{l}\text { - processes } \\
\text { measurement } \\
\text { and control } \\
\text { system, } \\
\text { - vapour recovery } \\
\text { system, } \\
\text { - safety valve, } \\
\text { - sprinkler } \\
\text { system, }\end{array}$ & $\begin{array}{l}\text { D1 } \\
\text { (4) }\end{array}$ & $\begin{array}{l}\text { D1 } \\
\text { (4) }\end{array}$ & $\begin{array}{l}\mathrm{D} 2 \\
(8)\end{array}$ & $\begin{array}{l}\text { D1 } \\
\text { (4) }\end{array}$ & D2 (8) \\
\hline
\end{tabular}




\begin{tabular}{|c|c|c|c|c|c|c|c|c|}
\hline & & & $\begin{array}{l}\text { - bright light- } \\
\text { reflecting tank } \\
\text { paint coats }\end{array}$ & & & & & \\
\hline & & Fire/explosion & $\begin{array}{l}\text { - as above, } \\
\text { - lightning } \\
\text { protection and } \\
\text { static electricity } \\
\text { discharge } \\
\text { system, } \\
\text { - prohibition of } \\
\text { using tools other } \\
\text { than in Ex } \\
\text { execution }\end{array}$ & $\begin{array}{l}\text { C2 } \\
\text { (6) }\end{array}$ & $\begin{array}{l}\text { C3 } \\
\text { (9) }\end{array}$ & $\begin{array}{l}\mathrm{C} 2 \\
\text { (6) }\end{array}$ & $\begin{array}{l}\mathrm{C} 2 \\
(6)\end{array}$ & C3 (9) \\
\hline 7 & $\begin{array}{l}\text { Tank bottom } \\
\text { unsealing }\end{array}$ & Leakage & $\begin{array}{l}\text { - double tank } \\
\text { bottoms, } \\
\text { - tank leak } \\
\text { inspection, } \\
\text { - processes } \\
\text { measurement } \\
\text { and control } \\
\text { systems, } \\
\text { - tank ground } \\
\text { protection, } \\
\text { - industrial } \\
\text { draining system }\end{array}$ & $\begin{array}{l}\text { B1 } \\
(2)\end{array}$ & $\begin{array}{l}\text { B3 } \\
\text { (6) }\end{array}$ & $\begin{array}{l}\text { B2 } \\
\text { (4) }\end{array}$ & $\begin{array}{l}\text { B1 } \\
(2)\end{array}$ & B3 (6) \\
\hline 8 & Lightning strike & Leakage/fire/explosion & - as under point 1 & $\begin{array}{l}\text { B4 } \\
\text { (8) }\end{array}$ & $\begin{array}{l}\text { B4 } \\
\text { (8) }\end{array}$ & $\begin{array}{l}\text { B3 } \\
\text { (6) }\end{array}$ & $\begin{array}{l}\text { B4 } \\
\text { (8) }\end{array}$ & B4 (8) \\
\hline
\end{tabular}

Table 4 lists hazardous events, effects brought about by a specific hazardous events and preventive measures used in the storage tank farm. Moreover, risk values were determined for: $\mathrm{L}$ - people, $\mathrm{M}$ - property, $\mathrm{S}$ - Environment, $\mathrm{R}$ reputation. As a result, the general risk occurring in the storage tank farm was determined.

The first of the hazardous events is a leak at the outflow connection upstream the cut

off valve - this event may lead to the three most probable effects:

1) leak - in order to avoid the effects of a leak in the storage tank farm, preventive measures were implemented, namely:

- a tank curtain wall,

- a measurement and control system,

- an industrial draining system,

- ground protection,

- water monitoring,

- permanent operation supervision.

For each of the four parameters, the probability of the occurrence of a hazard was determined as an incidental event. For the first case - the people, the effects were assessed as not causing any injuries. For the second parameter the property, the effects were assessed as not causing damage. The environmental effects were determined as causing a small impact on the environment. For the fourth parameter - reputation, the effect were assessed as having no impact on the good name of the company. The general risk was determined as permissible. 
2) Fire - in the case of the hazard of a fire occurred due to leakage, the same safeguards are applicable as for the first of the effects - the leak hazard. In addition, the following safety measures were implemented:

- sprinkler system,

- fire-fighting system,

- fixed foam extinguisher system,

- lightning protection system (discharging static electricity),

- hydrant installation: water and foam types,

- prohibition of using tools other than in Ex execution,

- alarming systems,

- close-circuit television system.

For all the of four parameters, the probability of the occurrence of a hazard was determined as a little probable event. For the first case - the people, the effects were assessed as likely to cause slight injuries. For the second parameter - the property, the effects were assessed as likely to cause considerable damage to machinery and equipment. The effect for the third parameter - the environment were determined as likely to cause a small impact on the surrounding environment. For the fourth of the parameters - reputation, the level of effects was determined as having a local impact on the company's reputation. The general risk was assessed as permissible.

3) Explosion - in order to avoid explosion hazards, the same safeguards are used as for leak and fire hazards.

For all the of four parameters, the probability of the occurrence of a hazard was determined as a little probable event. For the first case - the people, the effects were assessed as likely to cause isolated fatalities. For the second parameter the property, the effects were assessed as likely to cause sizeable damage to machinery and equipment. The effects for the third parameter - the environment were determined as causing a local impact. The effects for the company's reputation were assessed as likely to cause a regional impact. The general risk was assessed as permissible.

The second of the hazardous events in the storage tank farm is a break of a storage tank - this situation may lead to the following effects:

1) Leakage - to avoid the leakage effects, the same safety measures were implemented as for the first of the hazards, which is a leak at the tank outflow connection upstream the cut-off valve.

For each of the four parameters, the probability of the occurrence of a hazard was determined as a little probable event. For the first case - the people, the effects were assessed as not causing any injuries. For the second parameter the property, the effects were assessed as not causing damage. The environmental effects were determined as causing a small environmental impact. For the fourth parameter - reputation, the effect were assessed as having a slight impact on the good name of the company. The general risk was determined as permissible.

2) Fire - to avoid fire effects, the same safeguards as for leakage are applicable. 
For all the of four parameters, the probability of the occurrence of a hazard was determined as a little probable event. For the first case - the people, the effects were assessed as likely to cause severe injuries. For the second parameter the property, the effects were assessed as likely to cause considerable destruction of machinery and equipment. The effect for the third parameter - the environment were determined as likely to cause a small impact on the surrounding environment. For the fourth of the parameters - reputation, the level of effects was determined as having a local impact on the company's reputation. The general risk was assessed as permissible.

3) Explosion - to avoid explosion effects in the case of a break of a storage tank, the same safeguards as in the above instances are applicable.

For all the of four parameters, the probability of the occurrence of a hazard was defined as a little probable event. For the first case - the people, the effects were assessed as likely to cause isolated fatalities. For the second parameter the property, the effects were assessed as likely to cause sizeable damage to machinery and equipment. The effects for the third parameter - the environment were determined as causing a local environmental impact. The effects for the company's reputation were assessed as likely to cause a regional impact. The general risk was assessed as permissible.

The thirds of the hazardous events in the process pumping station is a failure of the automatic pump control system (tank overfilling) - this situation may lead to the following effects:

1) Leakage - to avoid leakage effects, the same safety measures were implemented as for the first of the hazards - a leak at the tank outflow connection upstream the cut-off valve; however, measurement and control systems are no applicable in this case.

For each of the four parameters, the probability of the occurrence of a hazard was determined as an incidental event that is likely to occur. For the first case the people, the effects were assessed as not causing any injuries. For the second parameter - the property, the effects were assessed as causing minor damage. The environmental effects were determined as not causing any environmental impact. For the fourth parameter - reputation, the effect were assessed as having no impact on the good name of the company. The general risk was determined as permissible.

2) Fire - to avoid fire effects, the same safeguards as for leakage are applicable. For all of the four parameters, the probability of the occurrence of a hazard was determined as an incidental event that is likely to occur. For the first case - the people, the effects were assessed as likely to cause severe injuries. For the second parameter - the property, the effects were assessed as likely to cause localized destruction of machinery and equipment. The effect for the third parameter - the environment were determined as likely to cause a small impact on the surrounding environment. For the fourth of the parameters - reputation, the level of effects was determined as having a local impact on the company's reputation. The general risk was assessed as permissible. 
3) Explosion - to avoid explosion effects in the case of a break of the automatic pump control system, the same safeguards as in the above instances are applicable.

For all the of four parameters, the probability of the occurrence of a hazard was determined as a little probable event. For the first case - the people, the effects were assessed as likely to cause isolated fatalities. For the second parameter the property, the effects were assessed as likely to cause sizeable damage to machinery and equipment. The effects of the third parameter - the environment were determined as causing a small environmental impact. The effects for the company's reputation were assessed as likely to have a regional impact. The general risk was assessed as permissible.

The fourth of the hazardous events in the process pumping station is an unsealing in the vapour recovery system (a break of the pipeline or fittings) this situation may lead to the following effects:

1) vapour emissions - to avoid vapour emission effects, the following safety measures were implemented:

- a processes measurement and control system,

- inspections and maintenance,

- constant operation supervision.

For each the of four parameters, the probability of the occurrence of a hazard was determined as a little probable event. For the first case - the people, the effects were assessed as not causing any injuries. For the second parameter the property, the effects were assessed as causing minor damage. The environmental effects were determined as causing a small environmental impact. For the fourth parameter - reputation, the effect were assessed as having no impact on the good name of the company. The general risk was determined as permissible.

2) fire/explosion - to avoid the effects of a fire and/or explosion, the same precautions as for vapour emissions and, in addition, the following safeguards are applicable:

- lightning protection system and static electricity discharge

- prohibition of using tools other than in Ex execution,

- antiknock protective devices.

For all of the four parameters, the probability of the occurrence of a hazard was determined as a little probable event. For the first case - the people, the effects were assessed as likely to cause severe injuries. For the second parameter the property, the effects were assessed as likely to cause localized destruction of machinery and equipment. The effect for the third parameter - the environment were determined as likely to cause a small impact on the surrounding environment. For the fourth of the parameters - reputation, the level of effects was determined as having a local impact on the company's reputation. The general risk was assessed as permissible.

The fifth of the hazardous events in the process pumping station is a failure of the safety valve - this situation may lead to the following effects: 
1) vapour emissions - to avoid leakage effects, the same safety measures were implemented as for the fourth of the hazards - an unsealing in the vapour recovery system and, in addition, a vapour recovery system was used.

2) fire/explosion - to avoid the effects of a fire and/or explosion, the same precautions as for vapour emissions and, in addition, the following safeguards are applicable:

- lightning protection system and static electricity discharge

- prohibition of using tools other than in Ex execution,

- antiknock protective devices.

For each of the four parameters, the probability of the occurrence of a hazard was determined as fairly frequent. For the first case - the people, the effects were assessed as not causing any injuries. For the second parameter - the property, the effects were assessed as not causing any damage. The environmental effects were determined as causing a small environmental impact. For the fourth parameter - reputation, the effect were assessed as having no impact on the good name of the company. The general risk was determined as permissible.

3) fire/explosion - to avoid the effects of a fire and/or explosion, the same precautions as for vapour emissions and, in addition, the following safeguards are applicable:

- lightning protection system and static electricity discharge,

- prohibition of using tools other than in Ex execution.

For all of the four parameters, the probability of the occurrence of a hazard was determined as an incidental event that is likely to occur. For the first case - the people, the effects were assessed as likely to cause slight injuries. For the second parameter - the property, the effects were assessed as likely to cause localized destruction of machinery and equipment. The effect for the third parameter - the environment were determined as likely to cause a small impact on the surrounding environment. For the fourth of the parameters - reputation, the level of effects was determined as having a minor impact on the company's reputation. The general risk was assessed as permissible.

The sixth of the hazardous events in the storage tank farm is a tank overheating - this situation may lead to the following effects:

1) vapour emissions - to avoid leakage effects, the following safety measures were implemented:

- processes measurement and control system,

- vapour recovery system,

- safety valve,

- sprinkler system,

- bright light-reflecting tank paint coats.

For the hazard of vapour emission caused by a tank overheating, the probability level, the effect level and the risk are all identical as in the above case, i.e. the vapour emission caused by a safety valve failure. 
2) fire/explosion - to avoid the effects of a fire and/or explosion, the same precautions as for vapour emissions and, in addition, the following safeguards are applicable:

- lightning protection system and static electricity discharge,

- prohibition of using tools other than in Ex execution.

For the hazards of a fire and/or explosion caused by a tank overheating, the probability level, the effect level and the risk are all identical as for the hazard of a fire and/or explosion caused by a safety valve failure.

The seventh hazardous event in the storage tank farm is a leak at the tank bottom. This incident may result in leakage, therefore the following preventive measures are applicable:

- double tank bottoms,

- tank leak inspection,

- processes measurement and control systems,

- tank ground protection,

- industrial draining system.

For each the of four parameters, the probability of the occurrence of a hazard was determined as a little probable event. For the first case - the people, the effects were assessed as not causing any injuries. For the second parameter the property, the effects were assessed as causing localized damage. The environmental effects were determined as causing a small environmental impact. For the fourth parameter - reputation, the effect were assessed as having no impact on the good name of the company. The general risk was determined as permissible.

The last, eighth hazardous event is a lightning strike, which may result in leakage, a fire or explosion. In order to avoid the above-mentioned incidents, the same preventive measures as for the first event - a leak at the tank outflow connection upstream the cut-off valve, are applicable.

For each the of four parameters, the probability of the occurrence of a hazard was determined as a little probable event. For the first case - the people, the effects were assessed as likely to cause isolated fatalities. For the second parameter - the property, the effects were assessed as causing considerable damage. The environmental effects were determined as causing a local environmental impact. For the fourth parameter - reputation, the effect were assessed as having a regional impact on public agitation. The general risk was determined as permissible.

\section{CONCLUSION}

From the performed analysis of fire hazards in a selected fuel base centre - the storage tank farm, a potential for the occurrence of seven hazardous incidents and the effects that these incidents may cause for people, property, the environment and the company's reputation have been identified. For all of the hazardous events, the general risk has been assessed as permissible. 
For each of these events, the implementation of necessary preventive measures has also been proposed. Implementing these preventive measures will ensure working safety for the people and equipment. Although it might seem that a plant classified as having a high risk of a serious failure is hazardous not only to the employees, but also the environment, property or the company's reputation, the fuel base example proves how misleading this presumption may be.

The investigation has demonstrated that the fire hazards identified in the area of the selected fuel base centre are minimized by safety systems put in place. A basic element influencing the correct operation of a safety system is the constant analysis of hazards, risk assessment and control.

Safety matters and enhancing the employees' awareness of hazards occurring on a specific workstation are put first in the plant under study.

\section{REFERENCES}

Asystentbhp.pl, (2019). [online] Available at: https://asystentbhp.pl/zagrozenia-nastanowisku-pracownika-stacji-pa-950/ [Accessed 25 Jul. 2019].

Czerwińska, K., Pacana, A. (2018). Porównanie dokładności określania poziomu ryzyka zawodowego na stanowisku przemysłowym. Zeszyty Naukowe. Quality. Production. Improvement., 1(8), pp. 92-101.

Dyb. J., Miś. R., Zawadzki T. (2010). Eksploatacja stacji LPG. Wydawnictwo "KaBe".

Grabowska-Lepczak, I. (2017). Edukacja dla bezpieczeństwa - Aspekty teoretyczne i praktyczne. Zeszyty Naukowe SGSP, 62(1), pp. 7-23.

Grocki, R. (2003). Vademecum zagrożeń. Wydawnictwo Bellona.

Jajuga, K. (2009). Koncepcja ryzyka i proces zarządzania ryzykiem - wprowadzenie, w Zarządzanie ryzykiem. PWN, Warszawa.

Jajuga, K. (2005). Teoretyczne podstawy zarządzania ryzykiem. PWN, Warszawa.

Janicka-Panek, L. (2015). Wprowadzenie do dydaktyki bezpieczeństwa i higieny pracy. ITE-PIB, Radom.

Jarysz-Kamińska, E. (2013). Ocena ryzyka jako element zarządzania bezpieczeństwem. Logistyka, 6, pp. 230-237.

Kaczmarek, T.T. (2008). Ryzyko i zarządzanie ryzykiem. Ujęcie interdyscyplinarne. Difin, Warszawa.

Kokot-Stępień, P. (2015). Identyfikacja ryzyka jako kluczowy element zarządzania ryzykiem w przedsiębiorstwie. Zeszyty Naukowe Uniwersytetu Szczecińskiego, 74(1), pp. 533-544.

Krause, M. (2011). Praktyczne aspekty doboru metod oceny ryzyka zawodowego. Zeszyty Naukowe Politechniki Śląskiej, 59, pp. 173-190.

Krause, M. (2016). Zarys metodyki oceny ryzyka zawodowego w aspekcie analizy metod badań. Zeszyty Naukowe Wyższej Szkoły Zarządzania Ochroną Pracy w Katowicach, 1(12), pp. 74-88.

Kunicki, T., Matus, B., Zabielski, A. (2001). Nowoczesne tendencje w dziedzinie zapewnienia bezpieczeństwa na instalacjach chemicznych. Nowoczesne Gazownictwo, 2, pp. 31-35.

Michalak, J. (2004). Refleksje nad pojęciem ryzyka. Ruch Prawniczy, Ekonomiczny i Socjologiczny, 1, pp. 119-123.

Zawieska, W. (2009). Ryzyko zawodowe. Metodyczne podstawy oceny. CIOP-PIB, Warszawa.

PN-EN 61882:2016-07. (2016). Badania zagrożeń i zdolności do działania (badania HAZOP) - Przewodnik zastosowań.

Pruszkowski, L. (2015). HAZOP jako metoda wspomagająca zarządzanie bezpieczeństwem procesowym w przedsiębiorstwie. Acta Universitatis Nicolai Copernicus. Zarządzanie, 42(3), pp. 7-20. 
Romanowska-Słomka, I., Słomka, A. (2008). Zarządzanie ryzykiem zawodowym. Wydanie IV, Kraków-Tarnobrzeg.

Rączkowski, B. (1999). BHP w praktyce. Ośrodek Doradztwa i Doskonalenia Kadr Sp. zo.o.

\section{Abstract.}

The work identifies and analyzes fire hazards in a selected plant - the fuel base. On this basis, the risk of these risks was estimated and methods of their prevention were established using the PHA method.

Keywords: risk map, hazard map, risk management 